\title{
Factor XIII Measurement
}

National Cancer Institute

\section{Source}

National Cancer Institute. Factor XIII Measurement. NCI Thesaurus. Code C112277.

The determination of the amount of factor XIII present in a sample. 